\title{
Agency Costs and UnRegulated Banks: Could Depositors Protect Themselves? Catherine England
}

Advocates of federal regulation often argue that individual depositors lack the information necessary to choose a stable institution or to monitor its continued performance. Bankers are presumed to have neither the incentives nor the means to communicate accurate information about the market value and long-term stability of their asset portfolios, and depositors are believed to have no other sources of accurate data. Without government oversight, it is argued, consumers would fall victim to unscrupulous or inefficient bankers who would take depositors' funds and use them to make unsound or illegal investments. The so-called contagion effect, in which the failure of one or more unsound banks can undermine confidence in healthy institutions, is an outgrowth of this presumption that the banking industry is marked by insufficient and asymmetric information.

Federal regulation and supervision of banks is supported, therefore, both as a means of protecting "innocent" bank customers and as a means of protecting "innocent" banks from the negative effects often associated with the failure of other banks. These arguments are widely accepted as describing market failures that prevent the development of a stable unregulated banking system. But there is reason to question their validity.

Most markets can be described as suffering from incomplete and/ or asymmetric information. Yet in many cases some individuals turn over to others control of specified assets-either financial or physical-for a period of time, just as bank depositors hand over their funds to bank managers. The literature about agency costs focuses on the arrangements principals (those who entrust the management

Cato Journal, Vol. 7, No. 3 (Winter 1988). Copyright (1) Cato Institute. All rights reserved.

The author is Director of Regulatory Studies at the Cato Institute. She would like to thank Thomas Huertas, Charles Smithson, and Charles Maurice for helpful comments on earlier drafts. 


\section{Cato Journal}

of some resource to another) make with their agents (those who are entrusted). Contractual terms outline what is expected of the agents and the penalties for nomperformance, and provisions are often made for monitoring the agents' performance. Further, agents have reason to make an effort to signal potential principals about the quality of their effort. The problems and solutions identified by the agency cost literature are directly applicable to the problems expected to arise in an unregulated banking environment.

In the next section of this paper, applying insights available from agency cost literature, we will try to predict how bank managers and customers would behave if there were no federal regulation or federal deposit insurance. ${ }^{1}$ To provide support for the theory developed, we will then discuss the performance of banks in Scotland and the United States during their so-called free banking periods when banks were not subject to today's extensive regulatory network. A case can be made that unregulated banking would prove more stable than many observers believe, that information and monitoring systems would develop to guide depositors in the selection of a bank, and that consumers would find ways to protect their funds.

\section{Agency Costs and Unregulated Banking}

The agency costs literature argues that both agents and principals are aware of the potential conflicts of interest and abuses that can arise in an agency relationship. But neither group is expected to passively accept the limitations imposed by the potential problems and inefficiencies. The recognition of agency costs creates incentives for both groups to take steps to minimize and control the problem.

To protect their interests, principals have reason to develop and incorporate contractual terms designed to channel the behavior of agents in desirable directions and/or to limit their ability to engage in unacceptable activities. In addition, principals setting a value on agents' services will consider the costs associated with the principal/ agent relationship and reduce accordingly the compensation that would be paid to agents in a world of perfect information. Faced with the possibility of reduced compensation, agents will not only agree to contractual terms that reassure principals, but will also develop mechanisms that tend to make principals more confident.

It is not important whether agency cost control mechanisms are initiated by agents or principals. Many common contractual arrange-

${ }^{1}$ We will assume throughout this paper that there is no federal deposit insurance in an unregulated setting, 
ments can be explained in terms of controlling agency costs. Markets do develop means for protecting the interests of principals.

In their initial work on agency costs, Jensen and Meckling (1976) discussed the position of bondholders in relation to owner-managers as one example of an agency relationship. This is particularly applicable to the issue of unregulated banking as the depositors of a bank can be viewed as being in a position similar to that of bondholders. Deposits are liabilities of the bank and depositors are creditors of the firm. ${ }^{2}$ Viewing a depositor as a type of creditor raises agency cost questions as depositors (the principals) give control of their funds to bank managers (the agents) in return for specified services (for example, a convenient means of paying bills) and/or a positive return on the money balances deposited (that is, interest).

Bank managers may not share all the concerns of depositors or hold them with the same intensity, however; the two groups may operate under different sets of incentives. Consequently, depositors must be concerned that bank managers may (in the view of depositors) misuse the funds entrusted to them. This raises certain questions: In an unregulated, uninsured setting, can depositors be reasonably assured that deposited funds will be available when they seek to withdraw them? What mechanisms might banking customers develop to protect their interests and encourage desirable behavior on the part of depository institution managers? What reassurances would bank managers and stockholders develop to attract and hold depositors? In other words, how might agency costs be controlled in an unregulated banking relationship?

\section{Incentives}

While it is theoretically possible that, without regulation, the fundamental form of banking organizations could change, following Fama and Jensen (1983) we assume here that the corporate form of banking

\footnotetext{
"Under current banking practices, influenced no doubt by the overarching bank regulatory structure, the many bank customers who hold demand deposits and passbook savings accounts are able to require repayment of their funds on demand rather than having a contractually specified date for the return of their money. It is often argued, therefore, that bank managers face greater day-to-day uncertainty about the continued availability of a large part of their operating funds than do managers of nonfinancial firms. But the proportion of bank deposits payable on demand, especially at larger banks, is declining. The bulk of bank funds is now made up of short-dated time deposits, analogous to the commercial paper that funds the operation of relatively unregulated finance companies. Furthermore, as discussed below, the possibility exists that unregulated banks and their customers would use contractual changes to further limit the extent to which deposits payable on demand make up the institution's liabilities.
} 
would continue. Therefore we must consider the incentives and effective power of the bank's stockholders, managers, and depositors.

The stockholders. As currently regulated, banks are among the more highly leveraged firms in the country, obtaining 94 to 95 percent of their operating funds from deposits, that is, as debt capital. Whether such low equity capital ratios could or would be maintained if there were no government supervision will be discussed below. Certainly stockholders have reason, other things being cqual, to economize on equity capital.

As Jensen and Meckling (1976) have pointed out, however, when the bulk of a firm's operating capital is obtained as debt, the owners have an incentive to make investments that promise high payoffs, cvon if the probability of collecting final payment is relatively low. Bondholders and other creditors of the firm receive a fixed return on their investment and no share of any extraordinary profits, so the owner-manager of a highly leveraged firm can retain most of the gains from successful investments while sharing with the firm's creditors a large part of the costs of its failure. This tendency for more highly leveraged firms to take on more risk is especially true with corporations. Stockholders, by the nature of their limited investment, are better able to diversify their holdings across firms and sectors of the economy than are single entrepreneurs. Thus, while stockholders certainly do not want their bank to fail, they have an incentive to encourage risk-taking on the part of bank managers as they seek to maximize their total expected return. The more highly leveraged the bank, the more risk it can afford to pursue.

Depositors. We assume here that the bank's depositors are the most risk averse of the three groups considered (though of course, many individual depositors may be less risk averse than some bank stockholders). The depositors' primary interest, we postulate, is the eventual repayment of deposited funds (to themselves or to a designated recipient) and any interest that has been promised. Assuming depositors follow the norm for creditors in other markets, a bank's deposit customers would stand to gain relatively little from the institution's rapid growth or the pursuit of relatively risky profits with high potential payoffs. On the other hand, the depositors could suffer significant losses if the bank failed.

Bank managers. The fundamental goal of professional managers, we are assuming, is to maximize the expected value of their future income streams. In that pursuit, they will try to enhance the prestige associated with the positions they currently hold and to avoid failures 
that would generate charges of fraud or mismanagement. Because the long-term income and prestige of a bank's managers are more closely tied to the success or failure of a particular institution than is the financial security of the average stockholder, bank managers are likely to be more risk averse than corporate owners. (See, for example, Leonard and Zeckhauser 1985.) The precise degree of a bank manager's risk aversion will depend on the operation of the market for bank management talent and the degree to which individual managers are viewed as responsible for institutions' successes and failures.

The assumption that bank managers seek to maximize the expected value of a future stream of income implies that their risk-taking propensities can be affected by the policies of those who compensate them for their services. The exact position of bank managers on the continuum of risk-taking behavior that places stockholders at one end and depositors at the other, will depend, therefore, on the reward and punishment structures devised by stockholders and depositors. As the ultimate success or failure of the depository depends largely on the decisions made by bank managers, the question is, who will exercise the greater influence over their behavior: stockholders or depositors? The answer will depend on which group is in the better position to reward (or punish) behavior of which it approves (or disapproves). This suggests an inherent conflict between a bank's stockholders, who would encourage more risk, and its depositors, who would urge more caution.

Stockholders vs, Depositors. Stockholders, through the board of directors, will attempt to influence the behavior of bank managers principally through a structure of direct rewards-promotions, salary, bonuses, and other perquisites-established for the institution. Control also can be exercised indirectly through the stock market and the market for corporate control.

Thus, shareholders have at hand both internal and external mechanisms for controlling agency costs and managerial behavior. The methods of stockholders are potentially powerful and fairly well developed as a result of extended experience through time and across industries. But depositors responding to an unregulated banking system could, contrary to common perception, exercise even more influence.

The existing system of government regulation and insurance has stifled the development of market mechanisms through which depositors might control bankers' behavior. But bank depositors, particularly those controlling relatively large accounts, are in a position to exercise relatively direct control over the bank's managers. When a 


\section{Cato Journal}

depositor removes his funds from a bank, he directly reduces the resources available to the depository, even though no immediate sale of assets may be required. Given existing deposit contracts, if enough depositors became dissatisfied and responded by closing their accounts, the ensuing run could force a bank into failure in a relatively short time (if there were no government intervention), something disgruntled stockholders would find it much more difficult to do. Because of the potentially serious (even institutionally fatal) consequences of depositor displeasure, a bank's managers and stockholders could be expected not only to agree to, but also to attempt to develop, contractual terms that protect and reassure depositors.

An increased emphasis on safety. We assume that while the customers of unregulated banks might demand a wider range of financial services or nationwide access to their funds, their primary concern would be safety. Before considering how such a concern might manifest itself, it is worth noting that existing federal guarantees mute competition in this area.

Except in the wake of a large local bank failure or a widely publicized problem, bankers rarely discuss with depositors or potential depositors the relative stability of their banks. To indicate it is safe, a bank merely reminds customers that it is a member of the Federal Deposit Insurance Corporation and/or that deposits are "federally insured to $\$ 100,000$." Indeed, banks have been exempted from many disclosure requirements imposed on other institutions, ${ }^{3}$ but the main reason there is little information about the relative stability of individual institutions is that because of federal deposit insurance the public demand for such information is sharply reduced.

Widespread apathy about the details of the banking business or about the investment decisions of any particular bank is rational given the existing deposit insurance system. For depositors placing accounts of less than $\$ 100,000$, there is no practical reason to care about the future prospects of an institution, and even individuals depositing more than $\$ 100,000$ often find their funds protected as federal officials handling troubled institutions have demonstrated a preference for purchase and assumption agreements (that is, mergers) that fully protect all depositors.

\footnotetext{
${ }^{3}$ There have been recent moves to force more disclosure from banks-on the subject of loans to Third World countries, for example. There has also been a good deal of discussion about increasing the disclosure of relevant information both from banks and federal regulators as a means of enhancing the market's discipline of banks taking excessive risks.
} 
If there were no government guarantees and oversight, however, individual depositors would find it more worthwhile to gather information about the business practices of individual depositories. There would also be more reason for depositors to develop ways of monitoring and controlling the actions of particular banks. Huertas and Strauber (1986, p. 9) have argued that bank regulation and supervision limit the amount and type of discipline the market would otherwise impose because regulators are believed to fulfill the function that creditors or their trustees fulfill when loans are made to a nondepository firm.

\section{Control Mechanisms}

Even with improved public knowledge about depository institutions, not every consumer would need to study banks' balance sheets and loan portfolios before deciding where to place his funds. Many small stockholders rarely, if ever, read an anmual report or follow the daily developments that affect companies in which they have invested. Neither do bondholders rely on their individual resources to discipline the firms to whom they lend money. Covenants designed to protect the interests of bondholders are developed by the managing underwriters, and the covenants are monitored and enforced by the trustees for the issue and by the bond rating services (Huertas and Strauber 1986, p. 9).

The first, and simplest, step individuals could take to protect their financial interests in the face of unregulated banking would be to better diversify their personal financial portfolios. That is, even without detailed information about the stability of any specific bank, depositors could reduce their risk by placing their savings account(s) in a bank (or banks) other than the one that held their checking account. In addition, however, it is logical to expect mechanisms to develop through which depositors as a group could monitor and control unregulated banks. Possible control mechanisms can be considered in three broad, though not entirely exclusive, categories: 1) sources that provide information about particular institutions, 2) parties other than the bank's stockholders or depositors who can monitor the behavior of bankers, and 3) contractual terms that expand or more fully define the legal obligations of bank stockholders and managers to depositors in the event the bank fails.

Sources of information. Independent sources of information about the relative stability of individual depositories could include independent bank rating services, money brokerage services, and/or 


\section{Cato Journal}

financial auditors. ${ }^{4}$ Bank rating and money brokerage services could provide comparative analyses about banks' relative returns, services, and risk to clients. Some might act as agents themselves, placing the funds of clients in institutions that exhibit the desired risk/return trade-offs. In addition, the broadcast and print media as well as public libraries would be likely to subscribe to summary versions of such analyses in order to provide their customers with basic financial information. In fact, bank rating services might provide some information through news releases to establish name recognition and attract potential clients.

To substantiate their advantage, relatively stable banks would readily provide data to these third-party monitors, and banks that had performed particularly well in independent rankings would use that information in their promotional materials to confirm their claims of superiority. ${ }^{5}$ This willingness on the part of healthy banks to distribute information would place competitive pressures on those institutions that otherwise would be inclined to be less forthcoming.

Independent auditors could also play an important role in analyzing financial data about the health of depository institutions. Currently accepted accounting procedures allow auditors to base their reports on the book values of assets, which permit them to ignore or gloss over the true condition of many institutions. Indeed, the primary purpose of auditors' reports is currently not so much to evaluate the overall health of an institution as it is to ensure that the firm is complying with accepted procedures in preparing financial reports and income statements. If there were no government guarantees, however, depositors would have greater incentive to encourage independent auditors to issue more candid reports and to go beyond the job they do today. This could be accomplished through explicit or implicit contracts between auditors and depositors that held the auditors legally responsible for losses suffered by depositors because of inaccurate, incomplete, or misleading reports, ${ }^{6}$ Or depositors could prove willing to deposit significant sums only in those depositories

\footnotetext{
${ }^{4}$ Bank rating services already exist, both independently and as parts of larger brokerage firms, to advise investors regarding bank stocks, nondeposit bank debt issues, and bank CDs. Such services, and others like them, could be expanded and developed as more depositors sought information about the relative stability of various institutions.

${ }^{5} \mathrm{~A}$. M. Best's rating of insurance companies is often used as a marketing tool by those firms that perform well.

${ }^{6}$ Independent audits can be used to provide the necessary information to control the behavior of bankers. Swiss banking supervisors do not employ bank examiners of their own. They rely entirely on the reports produced by the banks' independent auditors.
} 
that had received a favorable audit from an accounting firm with a reputation for accurate reports.

Another source of readily available information would be the prices charged for the funds made available to banks, that is, the interest rates banks paid to attract deposits. Market prices reflect the perceived risk attached to various investments, and without government guarantees, the market for bank debt would undoubtedly become even more sensitive to relative depository risk. As the market's perception of the risk associated with deposits in an institution rose, the interest rate that depository would need to offer to attract and hold funds would also rise. ${ }^{7}$

Outside monitors. In addition to new sources of information, depositors might also employ third party monitors to influence the activities of bank managers. In some cases, the function of providing information and the use of third-party monitors would be closely related; in others, large depositors in particular might include covenants in deposit contracts that required agreed upon third-party monitoring of the bank in question.

Consider the role of money brokers mentioned earlier. Money brokers now place large deposits where they will earn the highest return. Since the FDIC guarantees accrued interest as well as principal, this brokering process represents a no-lose situation for riskaverse individuals who break up larger sums into $\$ 100,000$ deposits.

Under the no-regulation, no-federal-insurance scenario, money brokers might still place deposits for their customers, but the purpose would be to reduce the risks of depositors through diversification and to take advantage of the brokers' relative expertise in evaluating and monitoring individual depository performance. Thus brokers would probably compete, in part, on their ability to accurately measure risk and anticipate changes in the prospects of depositories in which they placed clients' funds. Successful brokers would not only identify those institutions paying the highest rates, they would also need to consider the risks associated with different depositories.

In an unregulated market, depositors might also demand private deposit insurance, sold either to depository institutions or to individual depositors. For private deposit guarantors to manage their own risk exposure, they would need to develop a means for accurately assessing the risk embodied in individual banks. If private insurance

${ }^{7}$ This is true to some extent today. Interest on certificates of deposit exceeding $\$ 100,000$ vary with the perceived soundness of the institution offering the CD. 


\section{Cato journal}

were provided through the depository, as federal guarantees are now, insurance premiums would vary with the expected future health of the client institution, raising or lowering the costs of operating the bank depending on the managers' investment decisions. Further, the guarantor could develop contractual mechanisms for controlling the risk taken on by bank managers-capital or reserve minimums, for example, or requirements that certain actions be approved by the insurer before being undertaken. ${ }^{8}$

Selling deposit insurance policies directly to bank customers would not eliminate the need for guarantors to monitor the financial health of individual banks. It would, however, provide depositors with another index to the relative health of various institutions. The managers of banks assuming greater than average risk would offer higher interest rates to attract funds, but customers seeking to insure those deposits would also have to pay higher insurance premiums. ${ }^{9}$

The activities of banks not subject to government oversight could also be monitored through self-regulatory organizations formed by bank managers and stockholders who believe that the stability of their institution is at least partly dependent on the stability of other depositories. Industry-sponsored monitors could be local, regional, or nationwide collections of institutions that agreed to make funds available to troubled members under contractually specified conditions. The emergency funds could be deposited in advance in a common pool managed by representatives of the member institutions, or membership agreements might specify the conditions under which healthy institutions would be expected to make a loan to or buy assets from an illiquid fellow member. To minimize the risk associated with such agreements, participating bankers would want to be sure other member institutions maintained certain prudent standards of behavior, so a self-regulatory organization might establish minimum capital and reserve requirements, for example, and/or "prudent" lending standards. It could also develop ways to monitor member performance and to expel members who failed to meet minimum requirements. Self-regulatory mutual support organizations might develop a logo or trademark that member institutions could use to signal depositors about the standards of banking practice

\footnotetext{
${ }^{8}$ For a more complete discussion of how private deposit insurance might work, see England and Palfy (1983), England (1985), or Ely (1985).

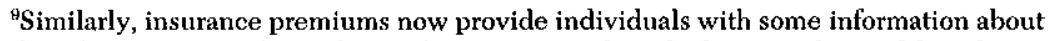
the relative structural soundness of competing car brands, for example, or of the relative hazard associated with different careers.
} 
adhered to and the extent of external support available in the event of trouble. ${ }^{10}$

Contractual relationships. The contractual relationships between bank stockholders or managers and depositors in an unregulated banking environment could also change. If the objective of depositors is to limit risk-taking, they should attempt to reduce the gains associated with successful risk-taking and/or to increase the costs of failure as measured by bank managers and stockholders. Of course, this generally will not be accomplished through individually negotiated contracts between depositors and their banks. While some very large depositors might exercise such direct power, most changes would arise as bank managers and stockholders offered different combinations of contracts and organizational structures in an attempt to attract more depositors. A successful contractual innovation that better protected the interests of depositors would attract customers (and hence funds) from other banks. These banks, to protect their market positions, would either match the innovative contract or attempt to improve on it. In this way, the market would evolve in a manner that reflects the concerns of depositors.

For example, unregulated banks might find it advantageous to increase their paid-in capital above what is currently enforced by federal regulators. As Modigliani and Miller (1958) established, individuals and firms (including banks) lending to highly leveraged companies compensate for the additional risk by increasing the interest rate charged. In the absence of government regulation and deposit insurance this same principle would apply to banks. Thus, unregulated depositories would find their cost of funds reduced as their equity capital increased, other things being equal. Of course, the optimal mix of debt and equity capital would vary from bank to bank depending on the risk associated with different asset portfolios, the stability and long-term prospects of the markets and industries served by individual banks, and the risk-taking characteristics of the customers of the various institutions.

Another possibility would involve extending the shareholders' liability in a failure beyond their investment in the bank's stock. This

\footnotetext{
${ }^{10}$ The Best Western motel chain, for example, is actually made up of independently owned and operated firms. To use the name "Best Western," these hotels must meet specified standards for size of rooms, quality of service, cleanliness, etc. Thus, "Best Western" was designed to provide customers with information about the quality of certain independently operated models, and the continuing value of this "name brand capital" depends on how well the private supervisor enforces established standards of operation.
} 
would give depositor's a claim against assets of the shareholders beyond the paid-in capital of the bank. Recent proposals have suggested that shareholders should be required to contribute an additional amount up to the par value of their investment to cover any losses. This "double liability" should increase shareholders" incentives to encourage bank managers to avoid failure. ${ }^{11}$

As an alternative to requiring extended liability for stockholders, depositors in an unregulated environment might choose to patronize only banks that included a portion of subordinated debt in their capital accounts. As fellow creditors, the interests of subordinated debtholders are more closely aligned with depositors than with stockholders or bank managers but, by definition, such debt does not threaten the ability of depositors to recover their funds in the event of a failure. If the debt were structured so that a portion matured at regular intervals, the sale of subordinated debt would provide depositors with regularly updated information about the market's assessment of the health of the bank in question. ${ }^{12}$

Depositors might also be willing to accept innovations that would help protect against occasional illiquidity. For example, a bank caught short on cash, but generally recognized as solvent, might convince a customer seeking access to his funds to delay his request for a specified period while the banker generated additional liquidity. Alternatively, the banker might issue a "promise to pay" that would be accepted as a cash substitute by local merchants or other depositories. In return for the forbearance of the depositor or for acceptance of the promissory note, the banker would provide an interest bonus or forgo some fee. In fact, the contractual terms applied to demand and savings deposits might be changed in a way that would give bank managers the option to limit withdrawals for a specified period of time or to require prenotification before an account was closed. ${ }^{13}$

\footnotetext{
${ }^{11}$ The oldest and most widely known form of banking in Switzerland is the so-called private bank. These institutions cater to a wealthy international clientele and emphasize investment management, brokerage, underwriting, placement of securities, and related bank functions. The owners of these banks, viewed as among the most stable in the world, accept unlimited liability in the event of failure (Corti, p. 4.6.10).

${ }^{12}$ While it is generally accepted that the use of subordinated debt as part of a bank's capital structure would tend to reduce bank risk, Black et al. (1978) observed that in at least one respect the use of subordinated debt would tend to increase the marginal incentives for risk-taking. By allowing banks to substitute subordinated debt for equity capital, stockholders would further increase the leverage of the firm. As noted, stockholders of a highly leveraged firm generally are less risk averse than they would be if their contribution to the firm's working capital were proportionately greater.

${ }^{13}$ Before 1933, savings banks had a clause in their deposit contracts requiring depositors to provide a 60 -day notice prior to withdrawing their funds. Generally, this notice was waived, but during panies or cash shortages, the savings banks would invoke the requirement.
} 
Such a clause is more than a means of protecting the bank's stockholders and managers. It would also protect bank customers, for it would remove the threat that either an unexpectedly large demand for cash or a panic-driven run would impose disproportionate losses on those who did not react quickly. Because the bank's managers and/or directors could delay payments, those depositors who believed the institution to be solvent would have no reason to join and reinforce a panic even if others attempted to close their accounts. And if the bank were truly insolvent, it could be closed and liquidated in a more orderly manner than is possible in the face of a run. There would no longer be any significant advantage to being first in line and hence no reason concern among some bank customers should generate a panic that could become a self-fulfilling prophecy.

Finally, to protect their funds, depositors placing large sums or money brokers acting on behalf of clients might place contractual constraints on the behavior of bank managers. For example, in an unregulated, uninsured banking system, it might be that only those institutions with deposits backed by easily marketable assets would survive, that is, mutual funds-type organizations. (See Fama 1980.) Other constraints might limit the life of loans made by depositories, the ability of bankers to concentrate loan portfolios in a particular region or industry, or the size of loan bankers could make to any one lender.

Much of the foregoing discussion about the sources of information and contractual protections that might develop without government oversight is, of necessity, speculative. It is difficult to predict exactly what form changes designed to control agency costs between depositors and banker's would take. Clearly, however, no one directly involved benefits from a run on a solvent institution. In an unregulated, non-federally-insured banking environment, therefore, bank managers and stockholders would have good reason to accept, even initiate, changes in contractual arrangements that would generate a sense of confidence among depositors. Those institutions able to develop attractive, effective protection mechanisms for depositors and incorporate them into their operations would attract funds from other banks less attuned to the concerns of consumers.

Naturally, it is unlikely that an unregulated banking industry would develop the uniformity of contractual terms apparent in today's highly controlled environment. That is, some depository institutions could be expected to cater to the most risk-averse depositors. These banks might offer deposits backed only by highly liquid assets, for example. Other, less risk averse individuals would be attracted by institutions offering a wider range of services and higher rates of return. In short, 


\section{Cato Journal}

if there were no federally enforced standards of uniformity, the banking industry would be expected to become more heterogeneous than it now is. Each institution would attract subsets of the broad spectrum of consumers whose needs and preferences best matched its mix of contractual terms and risk/return trade-offs.

\section{Failures}

In the absence of government regulation, bail outs, and deposit insurance, the potential for more frequent bank failures exists, so two questions must be addressed: (1) What response, if any, would the failure of one institution elicit from stockholders and managers of other banks? and (2) What response, if any, would the failure of one institution elicit from depositors of other banks?

Other bankers' reaction to failure. How the managers and stockholders of healthy institutions might respond to the actual or imminent failure of another bank will depend on many variables-the size of the failed bank, the extent of losses to depositors, its membership or nonmembership in a mutual support organization, and the publicly accepted reasons for the bank's failure, to name but a few.

Healthy depositories would attempt to distance their operations frorn those of the failed bank. Bank managers would make an effort to explain how their operations were different, how their management was superior, or how their portfolios were safer than those of the defunct depository. The point would be to convince depositors that the failure of one institution implied no more than that bad decisions were made at that bank. The remaining, healthy institutions could even gain by the demise of a competitor, and they would want to make sure their customers understood that.

If bankers believe that all depositors are more likely to panic when any one institution fails, then sound banks might take steps to facilitate the quiet, orderly liquidation of a troubled institution. Solvent banks could work together to evaluate and purchase the assets of the troubled bank, including its physical assets and its loan portfolio. Healthy institutions individually might take steps to minimize the costs of failure to the affected depositors. To attract as new customers the depositors of an institution forced to close, for example, remaining banks might offer loans backed by individuals' claims on the insolvent depository.

Mutual support or self-regulatory organizations would have even more reason to facilitate the liquidation of and protect the depositors of an insolvent member institution as the confidence instilled by their operation under an organizational umbrella would depend in 
part on how the organization handled such a crisis. Therefore, such organizations might develop methods of distributing assets to fellow members so that funds could be raised promptly and depositors paid.

Other depositors' response to failure. Panic-generated runs are presumed to occur because depositors are unable to differentiate healthy from unhealthy institutions. When some weakness causes the failure of one bank, it is believed that consumers will ascribe similar frailties to other institutions and that they will question the stability of all remaining banks. If enough depositors are sufficiently concerned to withdraw their funds from the banking system while awaiting additional information, a general collapse can ensue. ${ }^{14}$ Therefore, the important question is whether depositors in an unregulated setting would have confidence in their ability to differentiate healthy banks from unsound ones. If depositors felt they could make such distinctions, they would be unlikely to remove funds from one bank solely because another had failed, and funds that were removed from questionable depositories would be quickly redeposited in other institutions.

Without federal regulation and insurance, the returns to depositors investing in information about the banking industry generally and about specific depository institutions would increase. This increased interest among depositors in the relative strength of banks would lead to an increase in the availability of both comparative and absolute information. In an unregulated setting, then, there would be a greater demand for and a greater supply of information about the strengths and weaknesses of various institutions than now exists.

Consequently, depositors as a group would be better informed about the business of banking as well as about the health of any particular depository than they are under the existing system. While increased information about banks would not eliminate the possibility of a run based on unfounded fears, additional knowledge should work to reduce the probability of such a scenario.

Reinforcing the argument that an unregulated banking system could be a stable one is the presumption that banks would become more differentiated, more heterogeneous in an unregulated environment. In an effort to identify the bank(s) that best met their individual needs, bank customers would compare (or hire someone to compare

\footnotetext{
${ }^{11}$ Runs on individual banks, even solvent banks, cannot threaten the system if the money is redeposited in other depositories. Indeed, such shifting of deposits will provide the banks receiving a net inflow of funds with the liquidity to extend loans to or buy assets from solvent, but illiquid competitors. It is a run on the system, when withdrawn funds are hoarded, that creates a cause for concern.
} 


\section{Cato Journal}

for them) the range of services, the returns offered, and the safety embodied in individual institutions. Through this shopping process, consumers would begin to differentiate among depositories rather than viewing them as similar in their essential characteristics. Given such differentiation, weaknesses uncovered at one depository need not lead depositors to assume that all or any other banks are likely to incorporate similar flaws. Thus, the more heterogeneous an unregulated banking system became and the more this heterogeneity was communicated to depositors, the more stable the industry could be expected to be.

Of course, a serious weakness revealed through one failure could be reflected in other institutions, and confidence in similarly situated depositories could, then, be undermined, generating depositor runs on all such banks. But such runs should be self-contained as the market would reject only those institutions exhibiting attributes determined to be undesirable. ${ }^{15}$ Further, those consumers removing funds from the suspect depositories should prove willing to redeposit them in another bank exhibiting different characteristics. The banking system would not be threatened, only certain banks.

\section{The Historical Evidence}

In an attempt to determine whether there is any validity to the foregoing predictions about depositors' ability to protect themselves, we will now examine the "free banking" periods in Scotland and the United States. The Scottish free banking era lasted roughly from 1716 until 1845. It was the less regulated of the two systems as there was neither a Scottish central bank nor government oversight of banking activities-including entry and exit. The U.S. "free banking" experiments occurred between 1836 and 1863. During this period, the federal government played no role in banking, so regulatory decisions were made at the state level. Many states instituted a system of relatively free entry. Anyone meeting the minimum capital and collateral requirements could obtain a bank charter and issue

\footnotetext{
${ }^{15}$ It can be argued that just such a situation touched off runs on state-insured savings and loans in Ohio and Maryland during the spring of 1985 . As it became apparent that the state insurance funds had failed to adequately police the behavior of managers at Home State in Ohio and Old Court in Maryland, depositors feared that similar illadvised and/or illegal practices were taking place at other state-insured institutions. Once there was reason to doubt the efficacy of the formerly trusted supervision structure, depositors were no longer willing to leave their funds in the thrifts in question. Support for this thesis arises from the facts that, first, uninsured savings and loans in Ohio were not threatened by the runs and, second, at least during the Ohio crisis, other state systems remained largely unscathed.
} 
bank notes. It would be a mistake to view these banks as unregulated, however, as the various states imposed branching restrictions and reserve requirements, for example. Still, there were fewer restrictions than exist today and, of course, there was no federal deposit insurance..$^{16}$

Deposit banking played a much less important role during the 18th and 19 th centuries than it does today. ${ }^{17}$ Instead, each bank issued its own currency and the concern was whether a bank's notes would be accepted by others and/or whether they could be redeemed for specie (gold or silver coin). Further, the claim of noteholders against the assets of a failed bank superseded depositors' claims. As Hildreth (p. 155), writing in the early 19th century, explained, "[I]t is a voluntary thing for [depositors of a bank] to become such, and they may properly be left to select a depository for themselves, and stand any loss which that voluntary selection may involve." Noteholders received somewhat more sympathy because it was more difficult to control the selection of notes one held at any particular moment in time.

Recent historical evidence indicates that these earlier banking systems were not as chaotic and unstable as they are often portrayed. ${ }^{18}$ Much of the explanation may lie in the markets' responses to the agency costs discussed above.

\section{Sources of Information and Third-Party Monitors}

The restrictions on branch banking in the United States led the 19th-century money brokers to locate in larger towns and commercial centers so they could buy and sell notes from across town or across the country. "Foreign" notes could be exchanged for either local currencies or for specie. Not all bank notes circulated in every location at par, of course, and the discount attached to a particular issue, its "specie price," was determined by the local money brokers. The market value of a particular bank's notes generally depended on the bank's location (particularly its distance from the broker setting the discount) and available information about the condition of the issuing bank (Rockoff 1974, p. 143). ${ }^{19}$

\footnotetext{
${ }^{18}$ For a description of the Scottish free banking system and its performance, see White (1984). For a description of the various U.S. "free banking" systems, see, for cxample, Rockoff (1975).

${ }^{17}$ This is evident in debates over whether demand deposits constituted part of the money supply (see Mints, pp. 127-28) as well as in the general lack of concern about the losses suffered by depositors as opposed to noteholders in the event of a bank failure.

${ }^{18}$ See, for example, White (1984) and Kaufman (1988).

${ }^{10}$ Jay Cooke began his career as a bank note expert for E. W. Clark and Company of
} 
Information about the discount rates attached by the brokers to specific note issues was published in "bank note reporters." These newspaper-like periodicals, usually published weekly, listed each bank by state and county along with the discount on its notes in the city for which the reporter was published. The reporter also described and identified all counterfeit notes and notes from banks that had failed. This was a cumulative list, reporting failures that had occurred and counterfeits that had been removed from circulation years before. Merchants and bankers not only could readily determine the market value of any unfamiliar notes presented in payment for goods or in exchange for other notes or specie, they also were protected from attempts by others to reintroduce notes earlier deemed valueless. (See Hammond, p. 703; Rockoff 1974 , p. 143.) ${ }^{20}$

In addition to providing a service to travelers and local bankers by exchanging notes issued by out-of-town banks, the brokers also provided an important disciplinary function by returning notes for redemption-even when they circulated outside a bank's home market. When Minnesota suspended construction on its railroad in 1859 , the value of its railroad bonds fell sharply. State officials proved reluctant to reduce the legal price of the depreciating state debt and force banks to contract their note issues or contribute more capital to support their operations; the money brokers provided the discipline. ${ }^{21}$ Within six months, brokers in St. Paul began a systematic attack on those banks holding large sums of railroad bonds as backing for their notes. The brokers collected and returned the notes for redemption, thus forcing the banks to improve the quality of their collateral by threatening to drive them ont of business (Rockoff 1975, p. 110). In 1858, Chicago brokers imposed discipline on Wisconsin

Philadelphia, for example. As an expert on bank notes, Cooke could "recognize at sight notes from all over the country, could distinguish the spurious and the counterfeit, and knew the varying value of those that had value" (Hammond, p. 702). In describing his company's brokernge activities during 1839 and 1840 , Cooke wrote, "Our office is continually crowded with customers, and we do a tremendous business. We buy and sell at from $1 / 8$ to $1 / 4$ for commission and thus in doing $\$ 50,000$ per day you will see it pays well" (Hammond, p. 703).

${ }^{20}$ Many scholars have viewed the heterogeneity of the 18th-and 19th-century currencies as increasing the costs of doing business and potentially slowing overall economic growth. In fact, verifying the value of an unknown bank note in 19th-century America was probably similar to the process associated with verifying the validity of a customer's Mastercard or Visa today.

${ }^{21}$ When the Minnesota banking authority sought guidance from the state's attorney general in dealing with the depreciating state railroad bonds, the attorney general replied that while the banking authorities had no legal obligation to accept the railroad bonds for more than their market value, in his opinion, they had a moral obligation to do so. (See Rockoff 1975, p. 108.) 
wildcat banks when they refused to accept the notes of 27 specific Wisconsin banks that had "located at inaccessible points, having no capital, doing no banking business, providing no means whatever for the redemption of their issues" (Hammond, p. 618). ${ }^{22}$

In Scotland, where wider branching and a nationwide note exchange system made money brokers less valuable, the banks themselves sometimes provided information about their financial health. In 1704 and again in 1728 when unexpected illiquidity forced the Bank of Scotland to temporarily suspend specie payments, the bank was able to satisfy its customers and maintain public confidence in its notes by publishing its accounts to demonstrate its solvency. In 1836, the Glasgow Union Bank began to regularly publicize its asset and liability status as a means of attracting customers. It thus became the first British bank to issue a detailed annual balance sheet, but others soon followed suit.

The note exchanges and clearinghouses. In 1751, the Bank of Scotland and the Royal Bank agreed to accept and regularly exchange one another's notes. The Aberdeen and the Perth United banks initiated a similar system of mutual acceptance and exchange in $\mathbf{1 7 6 1}$ to encourage merchants doing business between the two cities to hold the notes of the two banks. Perth United soon entered into a similar arrangement with Dundee Banking Company. By 1771, a nationwide note exchange system had developed in Scotland (White, pp. 30-31).

This note exchange system benefited both the bankers and the public. The acceptance by banks of one another's notes at par reduced the public's costs of accepting and using bank notes, which enhanced the participating banks" name brand capital and hence their ability to expand their note issues. But the Scottish note exchange system also provided a form of industry-imposed discipline.

The most dramatic example of this discipline was the failure of Douglas, Heron and Company, better known as the Ayr Bank, established in 1769. Through its note issues, the Ayr Bank extended a great quantity of bad credit. The note exchange system, to which the Ayr Bank belonged, rapidly returned the bank's notes to it and,

\footnotetext{
${ }^{20}$ The system did not always work, however, especially when the state interfered with the brokers' efforts to impose discipline. In Maryland in 1841, banks were explicitly released by the state from the legal obligation to redeem notes presented by brokers. The legislature took the view that "evil brokers" were seeking to carry off the community's specie to other parts of the country (Hammond, p. 691). And a Boston money broker was brought before a grand jury in Vermont for attempting to redeem in specie the notes of a Vermont bank. The Vermont attorney general maintained the broker was guilty of an indictable offense (Dewey, p. 74).
} 


\section{Cato Journal}

lacking the specie to settle its accounts with fellow members, the bank was forced to turn to the London money markets to raise funds. The Ayr Bank floated an increasingly large sum of "bills of accommodation" with London banks, but when the loans it had made in Scotland began to sour, the Ayr Bank found it could not roll over, let alone retire, its debt obligations in London. In 1772, the Ayr Bank was forced into liquidation when brokers and bankers in London refused to buy its paper (White, pp. 30-32). Thus, while the Scottish free banking system could not prevent the establishment of a bank with poor management, it could cause its failure within a fairly short period of time.

Similarly, the clearinghouses that developed in the United States during the 19th century were in a position to monitor the performance of member banks. ${ }^{23}$ Redlich (1968, vol. 2, pp. 46-47) observed that through the regular exchange of notes and settlement of balances, the stronger banks could compel weaker institutions to adhere to accepted standards of prudent banking behavior, Hepburn (1903, pp. 157-58), no great fan of free banking, nevertheless reported of the antebellum clearinghouse associations that:

The clearing-house fixed a cash reserve and bound each member to maintain the same; took the public into its confidence by publishing weekly reports of condition showing the standing of each bank. This action, more than any legislation, more than anything else, aided in building up a sense of moral responsibility to the public on the part of banks throughout the country, in restraining the undue expansion of note issues and the many other reprehensible practices which characterized the banking of that period.

The "sense of moral responsibility" admired by Hepburn was more probably effective market discipline imposed by noteholders armed with information.

Probably the best known example of a clearinghouse acting as a self-regulatory organization was the Suffolk System begun in $1824 .^{24}$

\footnotetext{
${ }^{23} \mathrm{As}$ the role of clearinghouses developed in the United States, one bank in the association would be assigned the administrative role of clearing other member banks' accounts. Each member bank kept part of its specie on deposit with this "central" bank, which in turn issued clearinghouse certificates of an equivalent amount to be used in the settlement of daily balances. (See Timberlake 1984, p. 3.)

${ }^{24}$ The Suffolk Bank of Boston entered the business of clearing country banks' notes as a profit-making venture, unlike the more typical cooperative associations established by member banks. The Suffolk Bank hoped to force the country banks to limit their note issues circulating within Boston and, thus, to create a larger market for its own notes. Further, the Suffolk Bank was interested primarily in collecting and clearing the notes of banks outside of Boston-in the surrounding countryside and in other New England states-as opposed to clearing the intracity notes, though it eventually did
} 
According to Trivoli $(1979$, p. 17), "The most striking achievement of the Suffolk System for Boston was the ultimate elimination of the discount on country bank notes... The Suffolk System worked as an effective protection of the public against unsound banks." The Suffolk Bank did not automatically accept any bank as a member of its system. Bankers that followed practices which could be expected to lead to an overexpansion of their notes were not included. The ability to monitor and control country banks' account "overdrafts" gave the Suffolk Bank considerable power over the loan policies of these banks. Through the power to insist on immediate payment in specie of notes sent back to the issuing bank and through the threat to remove a bank from its list of New England banks in "good standing," the Suffolk Bank effectively imposed its standards on the banks throughout New England. (See Trivoli, p. 19.)

Before it came to an end in 1858, the system compiled an impressive record. By 1850, the Suffolk Bank either directly or through other Boston banks cleared notes for about 500 New England banks, or basically all those considered sound (Hammond 1957, pp. 55154). The banking standards imposed by the Suffolk System improved the performance and stability of the banks that were members. In the panic of 1837, for example, not one Connecticut bank failed or found it necessary to suspend specie payments. Similarly, in 1857 , when the state of Maine declared a suspension of specie payments, all but three banks, almost all members of the Suffolk System, continued to redeem their notes in specie (Rothbard, p. 218). Even Bray Hammond (p. 556), a critic of free banking generally, admitted the Suffolk System worked:

The operation of the Suffolk Bank showed laisser faire at its best. With no privileges or sanctions whatever froin the government, private enterprise developed in the Suffolk an efficient regulation of bank credit that was quite as much in the public interest as government regulation could be.

Though not as geographically widespread as the Suffolk System, other successful clearinghouses were also established. In New York City, for example, sixty banks established the New York Clearing House in October 1853.

After the panic of 1857,42 New York City banks agreed to maintain specific reserve requirements (Hammond, p. 713). This voluntary reserve requirement soon became effectively binding on all mem-

that too. Despite these differences with the more typical clearinghouses, the Suffolk System provides a good example of private regulation of the banking system. For a more complete description of the operation of the Suffolk System, see Trivoli $(1979$, pp. 13-15). 
bers of the New York Clearing House. In 1858, James Gibbons, summarizing the overall impact of the New York Clearing House, reported the clearinghouse had "put an end to speculative banking in New York. It has exerted a powerful influence to arrest speculative commerce" (Hammond, p. 706).

Timberlake (1984, p. 2) viewed the development of the 19th century U.S, clearinghouse associations as a mutual defense system against illiquidity. The panic of 1857 provides an example of the ability of the clearinghouse association to protect individual banks and their customers. Reserves in the New York banks began to decline in August 1857, and when a prominent bank failed a full blown panic seemed likely. At first the New York banks wanted to curtail loans, the usual means of responding to a specie drain. But the clearinghouse banks agreed to "increase their loans so that the clearing-house balances of all of them would be increased proportionately and would cancel each other without reducing the slender stock of specie" (Timberlake, p. 3).

Meanwhile, the country banks had drawn down the balance of specie held with the New York banks and against which their notes were cleared. A policy committee of the New York Clearing House Association authorized the issuance of "clearing house loan certificates." These loan certificates were backed by the unredeemed notes of country banks which were held by the central bank of the association. The loan certificates were issued to the creditor city banks that had received country bank notes in the course of doing business. The loan certificates were used by members of the clearinghouse in lieu of specie in settling interbank balances.

The loan certificates differed from the usual clearinghouse certificates in that the latter were issued strictly in lieu of specie or other legal reserves while the loan certificates were extensions of credit by the clearinghouse policy committee to member banks during the emergency. The country banks that could not redeem their notes immediately agreed to pay 6 percent interest on the loans thus granted by their city bank correspondents. The city banks then used the country bank notes, still backed by securities deposited with the New York state authorities, as collateral for the new clearinghouse loan certificates. The city banks were, thus, able to furnish more of their own notes to pay depositors and extend loans. (See Timberlake, pp. 3-4.) The clearinghouse had found a way to conserve the specie held by its members and to avoid the expected panic.

\section{Contractual Terms}

Of course, the definition of free banking in the United States represented a change in the contractual terms under which notes were 
issued. Paid-in capital took the form of specified securities held by state banking authorities for safekeeping. In addition, stockholders of free banks in Massachusetts faced unlimited liability in the event of failure (Rockoff 1975, p. 125) as did bank shareholders in Scotland (White, pp. 32-41). ${ }^{25}$

The Scottish banks used unlimited stockholder liability as a means of competing to provide "safety" to their customers and noteholders. Limited liability became an option in Scotland 20 years before any banks adopted it. Apparently, bank owners and directors feared a loss of confidence: would result if they included "Limited" after their names. To further bolster confidence, 18th-century Scottish bankers often posted with the town clerk a personal bond guaranteeing payment of the bank's notes in the event of failure (White, p. 4l).

In 1730 the Bank of Scotland, to increase the bank's flexibility in the event of an uriexpected demand for specie by noteholders, began inserting an "option clause" into the obligation printed on its notes. The bank's pound note then promised to the bearer "one pound sterling on demand, or in the option of the Directors one pound and sixpence sterling at the end of six months after the day of demand" (White, p. 26). (This represented an annual interest rate of 5 percent.) Noteholders were apparently willing to accept the option as a means of protecting their interests in the event of illiquidity, and the bank did not exercise the option for more than 30 years after it was introduced.

\section{Failures}

Finally, there is evidence that failures did not prove as destabilizing during the Scottish and American free banking periods as many have supposed.

The failure of the Ayr Bank in Scotland in 1772 was the most spectacular during the Scottish free banking period, but it did not appear to imperil the banking system. Because of the nationwide note exchange system, few banks held many Ayr Bank notes at the time of its collapse. Although the public's demand for specie did increase in Edinburgh on the day of the Ayr Bank's demise, this "run" lasted for less than a full day. Eight smaller banks with close business ties to the Ayr Bank also failed, but for the most part the negative repercussions from the failure were short-lived. The Bank of Scotland and the Royal Bank in Edinburgh helped calm any public

${ }^{25}$ Furthermore, stockholders of all national banks and of many state banks were subject to double liability until 1937 . In fact, double liability was not completely eliminated for U.S. banks until after 1950 . 


\section{Cáto Journal}

fears by offering to accept at face value the notes of the defunct bank. In addition to helping maintain public confidence, the two banks were able to attract new depositors and increase their note issues. The Bank of Scotland and the Royal Bank also advanced specie to the three Glasgow banks to meet unexpected cash demands immediately following the Ayr Bank failure. In the end, the unlimited liability of the Ayr Bank's shareholders meant that the demands of all creditors were met in full (White, pp. 32, 45).

Rolnick and Weber (1986) examined the U.S. free banking period using data collected from state auditor reports in New York, Wisconsin, Indiana, and Minnesota (chosen to reflect a range of experiences with free banking). They sought to determine whether bank failures that occurred in clusters were evidence of a general loss of confidence in sound banks. In other words, did such failures indicate the presence of "contagion" or "spillover" effects often associated with unregulated banking systems?

Rolnick and Weber found four "clusters" of failures between 1841 and 1861. Notably, each group of failures was limited to a single state, leading Rolnick and Weber to look for explanations in the states' policies toward banks and/or state-specific events. In fact, Rolnick and Weber were able to explain three of the four clusters of failures by identifying real shocks that rightfully undermined the public's confidence in the banks that failed. When construction on the Minnesota railroad was suspended in the spring of 1859 , those banks whose notes were backed by Minnesota railroad bonds failed. In Wisconsin and Indiana, Minnesota railroad bonds were eligible securities for backing bank notes but, in fact, no banks in these states held these securities to any great extent in their portfolios. Apparently the public was aware of the securities actually held by these banks, for there was no increase in bank failures in these states (Rolnick and Weber 1986, pp. 884-86).

Wisconsin's problems occurred, by contrast, on the eve of the Civil War-between June 1860 and June 1861. Wisconsin accepted bonds from several southern states as bank note collateral. As the Civil War approached, the value of the bonds issued by states likely to secede fell rapidly in northern markets. Again, the public had good reason to reevaluate the stability of those banks that had deposited significant portions of southern bonds as backing for their notes. Among the banks and in the states where southern bonds were not accepted, there were no similar adverse affects (Rolnick and Weber 1986, pp. 886-87).

In short, the evidence presented by Rolnick and Weber (1986) indicates that during the free banking era consumers did differentiate 
among those banks exhibiting different portfolio characteristics. Bank customers could and did force the closure of several banks in a short period of time when the stability of those banks appeared threatened by changing conditions. But there is no evidence that runs then spread to institutions with markedly different and stable securities portfolios. That the market appeared to reject almost simultaneously several banks marked by undesirable traits should be viewed as a demonstration of market-imposed discipline and stability rather than as a sign of instability.

\section{Conclusion}

The agency costs literature suggests that in the absence of government guarantees and regulations, market forces would encourage the development of mechanisms designed to limit the costs to bank customers entrusting their funds to depository institutions. It has been argued that readily available sources of information would arise in response to consumers' demands for intelligence about the relative stability of competing banks. Furthermore, it would be in the interest of the stockholders and managers of banks to develop contractual terms and other mechanisms to reassure customers about the safety of their investments. Such "competition in safety," if communicated to consumers of bank services, would allow the banks that employed them to gain market share and to increase the stability of their institutions as depositors would be less likely to panic in the face of adverse news.

The periods of "free banking" in Scotland and the United States provide evidence to support these predictions. These banking systems, established in the late 18th and early 19th century in Scotland and in the mid-19th century in the U.S., were chosen as representing periods of relatively unregulated banking, though the Scottish system was much less regulated than the American system was. While deposit banking was of less importance during the 18th and 19th centuries than it is today, in some ways the important role bank notes played as bank liabilities creates an even more stringent test for the conclusions drawn from the agency costs literature. It can be argued, as it was during the free banking periods, that an individual has less control over the selection of bank notes he holds than over the bank(s) in which he deposits his funds.

It appears that bank customers in Scotland and the U.S. did have access to information about the relative stability of individual banks. Furthermore, in both countries the self-regulatory activities of note exchange systems and clearinghouse associations provided note- 


\section{Cato Journal}

holders with information about member banks. Noteholders also benefited from contractual terms designed to reassure bank customers. These differences were most apparent in Scotland, perhaps because it was considerably less regulated than the U.S. free banking system.

Finally, these banking systems appeared to be more stable than is commonly believed. Evidence indicates that when a cluster of bank failures did occur, it did so for reasons connected to the practices of or the securities held by the institutions. The public appeared able to discriminate between those banks that exhibited undesirable characteristics and those that did not.

In short, during the U.S. and Scottish experiences with free banking, the problems often associated with unregulated banking seem to be, if not absent, at least not as extensive as common lore would indicate. Bank customers were reasonably well informed, and the market developed mechanisms for protecting their interests in the face of incomplete information.

\section{References}

Black, Fischer; Miller, Merton H.; and Posner, Richard. "An Approach to the Regulation of Bank Holding Companies." Journal of Business 51 (July 1978): 379-411.

Corti, Mario A. Switzerland: Banking, Money and Bond Markets. Reprinted from George-Giddy: International Finance Handbook, Section 4.6, Volume 1, pp. 1-50.

Dewey, Davis R. State Banking Before the Civil War. New York: Johnson Reprint Company, 1972.

Ely, Bert. "Yes-Private Sector Depositor Protection is a Viable Alternative to Federal Deposit Insurancel" Proceedings of a Conference on Bank Structure and Competition. Federal Reserve Bank of Chicago, 1985, pp. $338-53$.

England, Catherine, "Private Deposit Insurance: Stabilizing the Banking Industry." Policy Analysis No. 54. Washington, D.C.: Cato Institute, June $21,1985$.

England, Catherine, and Palffy, John. "Replacing the FDIC: Private Insurance for Deposits." Backgrounder No. 229. Washington, D.C.: Heritage Foundation, December 2, 1982.

Fama, Eugene F. "Banking in the Theory of Finance."Journal of Monetary Economics 6 (January 1980): 39-57.

Fama, Eugene F., and Jensen, Michael C. "Agency Problems and Residual Claims." Journal of Law and Economics 26 (June 1983): 327-49.

Hammond, Bray, Banks and Politics in America: From the Revolution to the Civil War. Princeton: Princeton University Press, 1957.

Hepburn, A. Barton. History of Coinage and Currency in the United States and the Perennial Contest for Sound Money. New York: Macmillan Co., 1903. 
Hildreth, Richard. Banks, Banking, and Paper Currencies. New York: Greenwood Press, 1968.

Huertas, Thomas F., and Strauber, Rachel L. S. "Deposit Insurance: Overhaul or Tune-Up?" Issues in Bank Regulation (Winter 1986): 3-24.

Jensen, Michael C., and Meckling, William H. "Theory of the Firm: Managerial Behavior, Agency Costs and Ownership Structure." Journal of Financial Economics (October 1976): 305-60.

Kaufman, George G. "The Truth about Bank Runs." In The Financial Services Revolution: Policy Directions for the Future, chap. 2. Edited by Catherine England and Thomas Huertas. Boston: Kluwer Academic Publishers, 1988.

Leonard, Herman B,, and Zeckhauser, Richard J. "Financial Risk and the Burdens of Contracts." American Economic Review (May 1985): 375-80.

Mints, Lloyd W. A History of Banking Theory in Great Britain and the United States. Chicago: University of Chicago Press, 1945.

Modigliani, Franco, and Miller, Merton H. "The Cost of Capital, Corporation Finance, and the Theory of Investment." American Economic Review 48 (June 1958): 261-97.

Redlich, Fritz. The Molding of American Banking: Parts I and II. New York: Johnson Reprint Company, 1968.

Rockoff, Hugh. "The Free Banking Era: A Reexamination." Journal of Money, Credit and Banking (May 1974): 141-67.

Rockoff, Hugh. The Free Banking Era. New York: Arno Press, 1975.

Rolnick, Arthur J., and Weber, Warren E. "Inherent Instability in Banking: The Free Banking Experience." Cato Journal 5 (Winter 1986): 877-90.

Rothbard, Murray. The Mystery of Banking. New York: Richardson and Snyder, 1983.

Timberlake, Richard $\mathbf{H}$. "The Central Banking Role of Clearing Associations." Journal of Money, Credit and Banking (February 1984): 1-15.

Trivoli, George. The Suffolk Bank: A Study of a Free Enterprise Clearing System. London: Adam Smith Institute, 1979.

White, Lawrence H. Free Banking in Britain: Theory, Experience and Debate, 1800-1845. Cambridge: Cambridge University Press, 1984. 


\section{Evolution IN BANKING}

\section{A. James Meigs}

Catherine England argues that in an unregulated banking system without deposit insurance, various services and institutions would evolve to do what many people now think must be done by government. These new services and institutions would protect imnocent bank customers from unscrupulous or inefficient bankers who otherwise would use depositors' funds for unsound or illegal investments, and would protect innocent banks from the contagious effects of other banks' failures.

Then she reviews the experience of free banking systems in Scotland and the United States and finds that such services and institutions did in fact evolve in those periods, much as her theoretical arguments would have predicted.

I found all of this most agreeable and plausible. I would not change any of it.

Her paper raises some intriguing questions:

1. If the system she describes would be so efficient and stable, why has it not already evolved?

2. Why do we have instead the unsatisfactory system we have met here to complain about?

3. How should we expect the system to evolve in the future?

She did not try to answer those questions here. They were not in her assignment for this conference, although she undoubtedly has thought a lot about how we may get from where we are now to the system she describes. She said in her opening remarks that she was going to talk about what would happen the day after the revolution. But evolution of the new services and institutions would take more

Cato Journal, Vol. 7, No. 3 (Winter 1988). Copyright 1 Cato Institute. All rights reserved.

The author is an independent scholar and consultant who lives in Princeton, New Jersey. He was Senior Vice President and Chief Economist with the First Interstate Bank of California. 


\section{Cato journal}

than one day. Therefore, I believe she has raised a problem in understanding the evolution of complex systems.

My observations on this problem will apply not only to England's paper but to most of the papers presented at this conference. For help on this problem I turn to the work of Stephen Jay Gould (1987), who teaches biology, geology, and the history of science at Harvard. He recently illustrated the problem of understanding evolution with a homey example, the typewriter keyboard. He did this with the help of Paul A. David (1986), professor of American economic history at Stanford.

Probably everyone in this room types on the QWERTY keyboard, which is named for the first six letters on the top line. As Gould says, it is "drastically suboptimal." Some of the most frequently used letters are in hard-to-reach positions or are under the weakest fingers. There have been many competitors, including the Dvorak Simplified Keyboard (DSK). DSK is much faster. ${ }^{+}$But no competitors have ever dented the dominance of QWERTY.

Why? This is like our problem with banking. We have a "drastically suboptimal" banking system, even though a superior system might have evolved-or may yet evolve-as England argues. The QWERTY keyboard actually was designed to keep typists from typing too fast, to keep the keys from jamming on a primitive early machine invented around 1867. But why did QWERTY win out over all of its competitors after other machines came onto the market?

According to Gould and Day, a crucial speed typing contest was won on a QWERTY keyboard in 1888 by a typist who had the novel idea of memorizing the keyboard instead of using hunt-and-peck. He had invented touch typing. But the wide publicity his victory received led manufacturers and typing schools to standardize on QWERTY from then on. In short, an accident shaped the course of typing history. ${ }^{2}$

The story of QWERTY illustrates two commonplaces of history, says Gould:

1. Contingency. Mammals, or QWERTY, or our heavily regulated banking system are the chancy results of long strings of unpredictable antecedents, rather than the necessary outcomes of natural laws.

\footnotetext{
${ }^{1}$ There is software for shifting modern computer terminals to a DSK keyboard virtually at a keystroke. However, Apple reports little use of this high-speed alternative on its machines. One person from the audience at the Cato Monetary Conference told me that he had bought software to convert his IBM PC to DSK.

${ }^{2}$ As Gould says, competitions that would have tested QWERTY against other keyboards and other styles of typing were never held. In public perception and in the eyes of those who published typing manuals, QWERTY had proved its superiority.
} 
Evolution is not a simple, linear process. Chance events can nudge a process into a new pathway with "cascading consequences that produce an outcome vastly different from any alternative."

Two examples of such pivotal events in the history of the banking system that were stressed by several speakers at the conference are the establishment of the Federal Reserve System in 1913 and the Great Depression of the 1930s. Without the first, we would not have had the second, but the two combined had powerful effects on the evolution of banking.

2. Incumbency. The second of these commonplaces of history, incumbency, reinforces the stability of a pathway once such chance events push a sequence into a new channel. As Gould says, "Suboptimal politicians often prevail nearly forever once they gain office and grab the reins of privilege." That sounds more like a statement from the Center for the Study of Public Choice than the view of a Harvard professor of biology, but that is what he said.

He went on to say, "If every typist in the world stopped using QWERTY tomorrow and began to learn Dvorak, we would all be winners, but who will bell the cat, or start the ball rolling?" It is not easy. In banking, for each banker or regulator who wants to change the system there are probably ten opposed.

Where does all of this leave us? At the moment, we are stuck with a QWERTY banking system. It is the end result of a long chain of accidents. England as well as others have told us a better keyboard is available. However, because of the power of incumbency, a change of course will be difficult. We should not be too optimistic. After all, says Gould, "Mammals waited 100 million years to become the dominant animals on land and only got a chance because dinosaurs succumbed during a mass extinction."

I hope we don't have to wait for a mass extinction before we can move to Catherine England's more stable system. Fortunately, we are not like those little mammals waiting for the dinosaurs to die out. We can nudge history. In sum, I think we can read England's argument two ways.

In the first, which I call the Gradualist Approach, she says we should not be afraid to take any opportunity for moving even a little way in the direction of her ideal system. For example, we could reduce deposit insurance coverage to introduce more market discipline or take other measures discussed here. The system would not fall apart.

In the second, which I call the Big Bang, she assures us that if we do have a cataclysm, such as the extinction of the FSLIC and the 


\section{Cato Journal}

thrift industry, we would be ready to propose shifting the direction of evolution heavily toward a freer, more efficient system.

\section{References}

David, Paul A. "Understanding the Economics of QWERTY: The Necessity of History." In Economic History and the Modern Economist, pp. 30-49. Edited by W. N. Parker. New York: Basil Blackwell Inc., 1986.

Gould, Stephen Jay. "The Panda's Thumb of Technology." Nattral History (January 1987): 14-23. 